\title{
Selected technical aspects of well construction for geothermal energy utilization in Poland
}

\author{
Barbara Tomaszewska, Anna Sowiżdżał, Anna Chmielowska*
}

AGH University of Science and Technology, Faculty of Geology, Geophysics and Environmental Protection, Department of Fossil Fuels, Mickiewicza 30 Av, 30-059 Kraków

*Corresponding author: adrabik@agh.edu.pl

Received: $4^{\text {th }}$ July, 2018

Accepted: $30^{\text {th }}$ July, 2018

\begin{abstract}
Geothermal resources have been used in Poland since the 90s of the last century. Since then, several geothermal heating plants, recreation and balneological centers have been operated.

Accessing geothermal resources is possible due to deep boreholes that are either brand-new wells or old but revitalized petroleum and/or exploratory wells. In this case, the construction of production and injection wells is of significant importance. The utilization of deep geothermal energy resources is strongly dependent on the binding domestic law regulations - primarily in case of acquiring the concession enabling an execution of geological and drilling works, and subsequently a proper exploitation.

The paper presents the current state of development of the geothermal energy sector in Poland, indicating examples of exploitation systems based on deep boreholes. Furthermore, the constructions of existing wells are discussed extensively. The existing examples of old but reconstructed wells in Poland, are characterized. The importance of national law and its influence on the development of a geothermal investment is highlighted, as well.
\end{abstract}

Key words: geothermal energy, well construction, internal law, reconstruction

\section{Introduction}

Geothermal energy, as the total amount of internal heat (thermal energy) accumulated in the Earth is distributed unequally around the globe. Especially favorable geo-tectonic conditions for a formation of geothermal systems exist within the edge of lithosphere plates - in rift and subduction zones (Górecki (eds.) 2006). In these areas, the vast majority of most prospective high-temperature geothermal systems are located. Poland is not one of those, nevertheless, it has significant geothermal potential (heat flow values from $20-90 \mathrm{~mW} / \mathrm{m}^{2}$, geothermal gradients from 1-4 ${ }^{\circ} \mathrm{C} / 100 \mathrm{~m}$ (Kępińska 2015)) connected to low-temperature geothermal resources. Since, the terms of low- and high-temperature geothermal resources might be understood distinctively, for the present research, the boundary temperature is set as $150^{\circ} \mathrm{C}$ (Górecki (eds.) 2006). Conventionally, geothermal resources are divided into hydrothermal resources and petrogeothermal resources (Sowiżdżał 2018). Hydrothermal resources include reservoirs of hot water and/or steam, and are categorized as liquid- or vapordominated, respectively. Petrogeothermal resources, as opposed to hydrothermal ones, are not connected neither with water nor steam but with hot dry/hardly dry rocks (Brown et al. 2012). Instead, they are man-maid reservoirs within a rock formation that is artificially fractured (usually by the hydro-fracturing). 
The utilization system of such a reservoir has been called enhanced (engineered) geothermal system (abbr EGS) (Olasolo et al. 2016).

The subject area of geothermal energy sector has been discussed by plentiful researcher around the world, indicating various aspects (e.g. exploration, drilling activities, exploitation or utilization), encountered problems and possible ideas for further development (Bujakowski et al. 2013; Bujakowski and Tomaszewska (eds.) 2014). The item of effective exploitation of geothermal resources (Røksland et al. 2017) seems to be one of the most important issues, as well as an environmental (Kristmannsdóttir and Ármannsson 2003; Lacirignola and Blanc 2013) and economic (Bu et al. 2012) analysis. Also, the subject of broadly understood legal frameworks concerning the exploitation of geothermal resources has been introduced (Tomaszewska and Hołojuch 2012).

\section{Geothermal Energy in Poland}

Geothermal energy resources in Poland are related to the underground waters of various stratigraphic layers, within geological units main hydrogeothermal provinces: the Polish Lowlands, the Carpathians, the Carpathian Foredeep and the Sudetes (Fig.1). Generally, they are natural sedimentary-structural basins filled with geothermal waters with relatively high temperature range, namely, from $20^{\circ} \mathrm{C}$ to about $90^{\circ} \mathrm{C}$ (even in excess of $100^{\circ} \mathrm{C}$ ) (Kępińska 2015; Kępińska 2016). The information about the size and energetic potential of geothermal resources is widely known through results of numerous research projects accomplished so far (Górecki et al. 2015; Miecznik et al. 2015; Bujakowski et al. 2016; Sowiżdżał and Kaczmarczyk 2016). The recognition of geological structures either for direct or indirect applications of the geothermal energy is an important direction of proceeded geological research. The most prospective regions for a geothermal energy development in Poland are connected with areas characterized by a high value of heat flux and sufficient hydrogeological parameters, and are ascribed to Polish Lowlands and Podhale region, i.e. Western Carpathians (Sowiżdżał 2018). The principal resources of geothermal waters in the Polish Lowlands are accumulated within the Mesozoic groundwater horizons. Geothermal waters are accumulated mainly in the Lower Jurassic and Lower Cretaceous formations but significant resources of geothermal energy are assembled also in the Upper Jurassic, Middle Jurassic, Upper Triassic and Lower Triassic formations (Górecki et al. 2015). In the case of Podhale region, the resources of geothermal water are connected with the Mesozoic sedimentary formations (Kępińska 2015; Kępińska 2016). The most prospective aquifers occur within the Middle Triassic limestones and dolomites, as well as in overlying Eocene carbonates (Sowiżdżał 2018).

Since Poland is endowed with lowtemperature geothermal resources, primary applications involve space heating sector, bathing and recreation as well as balneotherapy (Fig.1). Nevertheless, the geothermal waters are also used in agriculture, aquaculture and for various industrial applications. In 2017, six geothermal district heating plants were operating: in Podhale region and municipalities of Pyrzyce, Mszczonów, Poddębice, Uniejów and Stargard Szczeciński (Kępińska 2016; Sowiżdżał 2018). Moreover, 17 recreation centers are located within the country, where geothermal water is used both for swimming pools and other facilities as well as for preparation of hot domestic water. Geothermal water is also utilized in 12 health resorts for curing and rehabilitation purposes. It is worth noting that numerous projects concerning distinctive geothermal aspects have been under development, including an indication if the utilization of existing geothermal potential is feasible and sufficient for electricity production (Kępińska 2015; Kępińska 2016). 


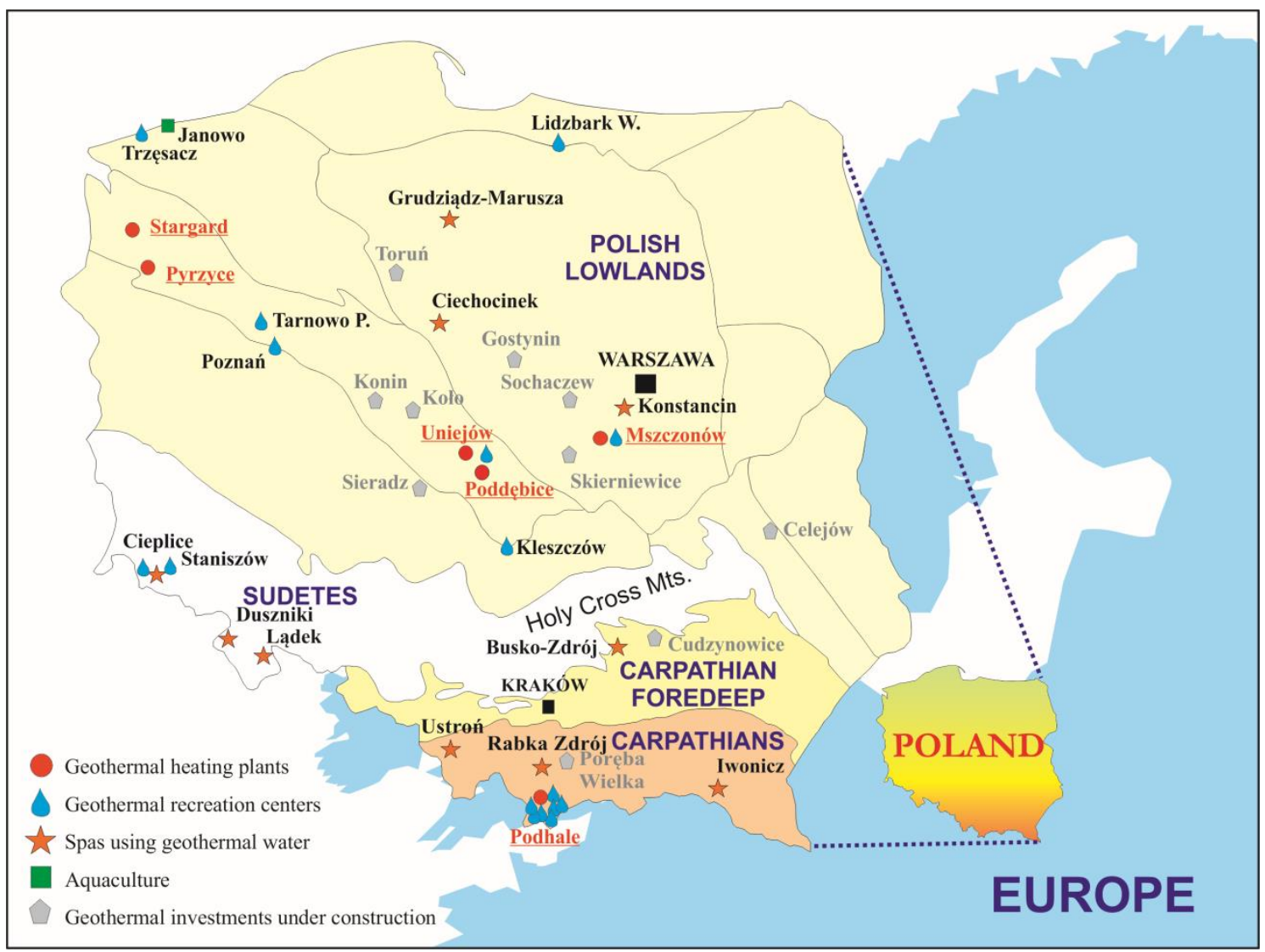

Fig.1. Geothermal energy in Poland; modificated after (Sowiżdżał 2018).

\section{Internal Law Regulations}

Generally, the text of the internal law in the context of geothermal energy utilization, has been strongly determined by the conditioning derived from the European Union. Such regulations allow to procced the efficient and sustainable exploitation, and then utilization of geothermal energy resources. What is more, the compliance with the formal and legal regulations, together with applying a goodpractice and mondial know-how during each stage of geothermal investment, enable the natural environment to be preserved against the possible negative impact (Tomaszewska and Hołojuch 2012; Sowiżdżał et al. 2017).

The most important legal act that regulates principles of the exploration, recognition and exploitation of geothermal reservoirs is the Geological and Mining Law (J.L. 2016 item $1131)^{\mathbf{1}}$, however, supported by numerous ministerial regulations. At first, it seems to be crucial to pay the attention to the notion of a "geothermal water", which is a term widely used among Polish and global scientific community and in literature. The Polish law (J.L. 2016 item 1131, Art. 5) introduces the term of a "thermal water", defining it as the underground water that temperature at the outflow of a water intake is not less than $20^{\circ} \mathrm{C}$. It is encountered for these terms to be used alternately, worldwide. Under the ordinance of the present act (J.L. 2016 item 1131, Art. 5 and 10), the geothermal waters are treated as minerals resources and the mining property right is appertained to the State Treasury. Simultaneously, the act constitutes that production mining activities exact obtaining of a concession, which can be conceded only

\footnotetext{
${ }^{1}$ For term Journal of Laws, the abbreviation J.L, created for this paper, is being used.
} 
by the marshal of a proper province (J.L. 2016 item 1131, Art. 21.1). What is a substantial convenience, in the case of exploration and recognition of thermal waters, there is no requirement to obtain the concession. Nevertheless, the development of a geological project as well as its submission to the aforementioned administration authority are essential duties of any investor.

Considering the process of the acquiring a concession for the exploitation of geothermal waters, the first stage is to elaborate the Project of Geological Works. The requirements that should be met by such a document are broadly described in the proper Regulation of the Minister of Environment (J.L. 2015 item 964). During the aforementioned phase, it might be essential to assess the possible impact on a natural environmental triggered by the projected enterprise. As specified in the Regulation of the Council of Ministers (J.L. 2016 item 71), drillings which depths exceed $1,000 \mathrm{~m}$ can significantly influence the natural environment, therefore, the obtainment of a decision on the environmental conditions of the project might be required. In such a case, the entrepreneur is bound by the law to submit (to competent authorities) the Information Card and/or Environmental Impact Report. These documents concern and specify the possible impact of future investment on the surface and groundwater quality, emission rate of different pollutants into the atmosphere, waste management, water and sewerage management, landscape, noise and vibrations emissions and electromagnetic fields. At the stage of geological works aimed at the exploration and recognition of geothermal water resources, the regulations delineated in the section VI (notably chapter 2) of the Geological and Mining Law (J.L. 2016 item 1131), concerning the broadly-understood operation of mining works ought to be employed. The results of the handled geological work, including the amount of exploitable resources should be set in the
Hydrogeological Documentation. This document ought to be prepared in the accordance with guidelines stated both by the Geological and Mining Law (J.L. 2016 item 1131, Art. 88) as well as the Regulation of the Minister of Environment on Hydrogeological Documentation (J.L. 2016 item 2033). It is worth to be emphasized that the Hydrogeological Documentation of a geothermal reservoir is a strategic document which constitutes the basis for be given consent to the quantity of extracted water and the method of exploitation. Additionally, in the case of a positive recognition of hydrothermal resources, the document has to define the conditions for the re-injection of spent water, with the clear indication of methods to be applied for the specific water intake towards its prevention against a phenomenon of well's clogging (so-called colmatation).

The stage concerning the obtainment of a concession for the mining of thermal waters is regulated by the section II, chapter 1 of the Geological and Mining Law (J.L. 2016 item 1131). The application for a such concession defines several important issues, like information on the amounts of geothermal resources and planned rate of extraction, geological and hydrogeological conditions of water extraction, as well as for the spent water re-injection into the rock formation. It should be emphasized that the obtained concession is an important document on the sustainable exploitation of the mineral deposits, moreover it remains the essential act determining the treatment of spent waters. What is quintessential, according to the Regulation of the Minister of Environment (J.L. 2014 item 812), the executive of a proper mining plant is of responsibility to prepare a specific technical documentation for each injection well separately. It is worth highlighting, that besides the strict environmental protection requirements (J.L. 2017 item 1405), this document includes also a description of how to eliminate 
or to constrain the negative impact of a potential exploitation of geothermal reservoir on the natural environment. As water is an extracted medium, other procedures must comply with regulations supplied by the Water Law (J.L. 2017 item 1566). Moreover, the spent thermal water, that is discharged into inland waters or to the ground is considered as the wastewater (J.L. 2017 item 1566), and its quality have to meet the requirements specified in a few documents referring to the protection of natural environment (J.L. 2017 item 519).

\section{Geothermal Well Construction}

Construction of a geothermal wells depends on several aspects, inter alios, geological conditions including downhole pressure, its target (production or injection) and whether it is a brand-new borehole or old revitalized borehole. Generally, geothermal well consists of elements such as casing of a proper diameter, a construction element allowing access to the reservoir and technical equipment like a deep well pump (if necessary). What is more, geothermal well can be vertical or, in order to get better access to the reservoir, directional one (Soboń 2006). Considering casing (Fig.2), five main types of columns are distinguished (Gonet et al. 2006): conductor column, surface column, intermediate column production column and liner-production column. According to Gonet et al. (2006), while designing the well one should pay attention to the length and the diameter of an individual casing, concerning information about geology, litho-stratigraphy, hydro-geology, pressure conditions and rock ability to change its state and shape. Generally, the drilling works are divided into two major parts, namely, setting the scheme of casing and examining the strength of a respective casing.

Since, the exploitation well can be located within area of different geo-tectonic conditions, various values of formation pressures might occur, what determines it construction. In case of artesian basins, the pumping equipment (thereby pumping chamber) is not necessary, by contrast to reservoirs under the sub-artesian pressure (Fig.2).

According to Biernat et al. (2012) and Gonet et al. (2006), each of aforementioned casings (Fig.2) has to fulfill its own tasks. The main assignments are discussed below, respectively for each casing:

- conductor column - preserves the borehole's mouth from being washed by a drilling mud and contamination of it walls through a dully-compacted soil;

- surface column - has to isolate waterbearing horizons (from itself), and in the exploitation well of artificial-lift system it has an additional assignment of being a pumping chamber;

- intermediate column - is used to close the water inflow (large) into the borehole, as well as for covering zones where there is a difficulty in conducting further drilling (e.g. leakage of a drilling mud). It is needed to be highlighted, there can be multiple number of intermediate columns, and in case of injection well it is usually led to the surface.

The issue of well construction in the zone of geothermal reservoir horizons is of great importance especially in the context of pursuing exploitation of hydrothermal resources. Different solutions for rendering the horizon accessible are available, namely, the no-filter construction - so-called "open-hole" type, the filter construction, the filter construction with borehole widening and gravel packing, and last but not least the filter construction made by perforation of casing pipes - so-called "cased-hole" (Soboń 2006). According to Kępińska and Bujakowski (eds., 2011), the proper selection of the construction can minimize the failure rate of the geothermal system. The construction and equipment of geothermal well (production and injection) 


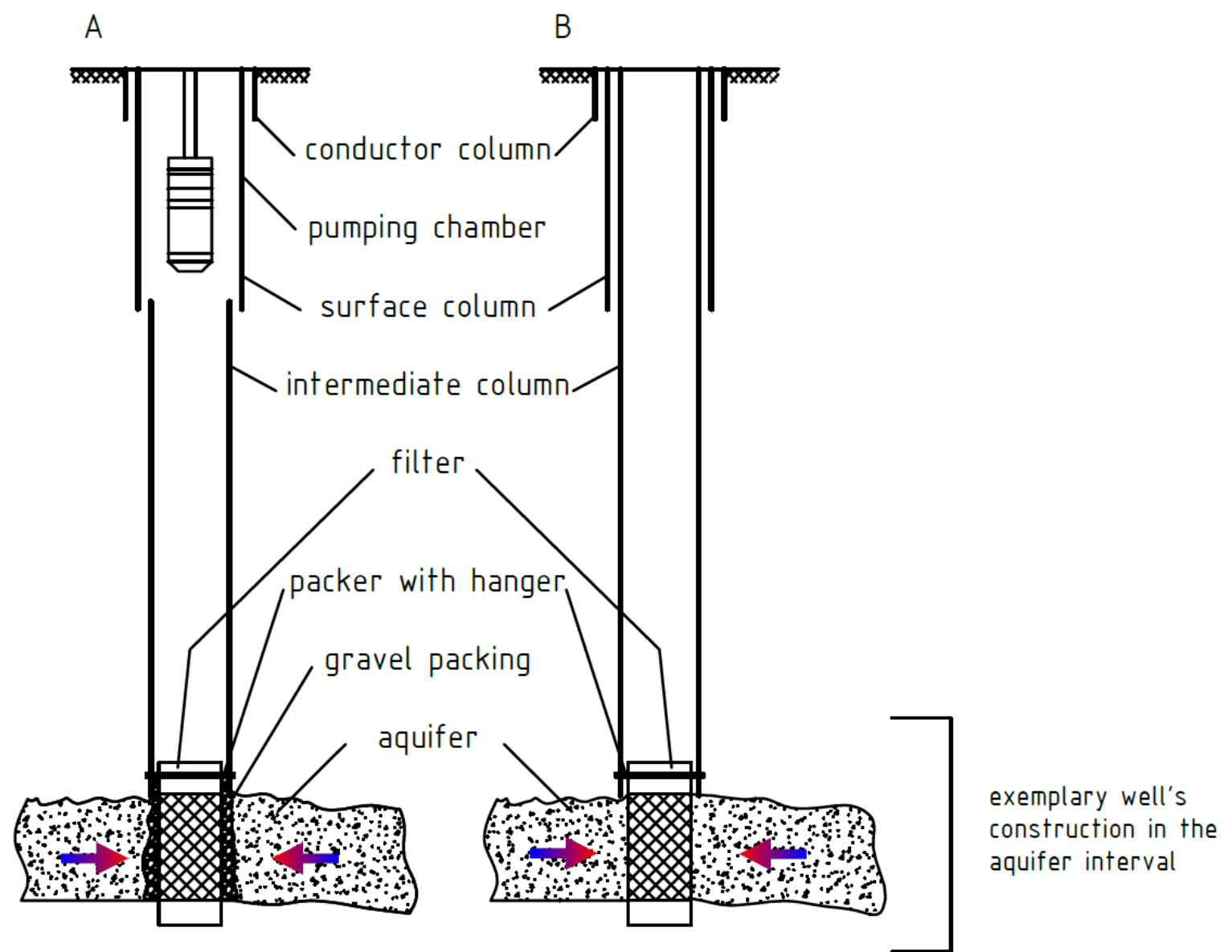

Fig.2. The schematic design of a production well construction in the area of sub-artesian (A) or artesian (B) formation pressure; based on (Biernat et al. 2012) with additions.

in the horizon interval is conditioned mainly by estimated capability of a well, depth of an aquifer, parameters of a reservoir (compactness, granulation, permeability, porosity), projected life-time (Tomaszewska and Pająk 2012). In the case of transformation of old petroleum/exploratory borehole into a geothermal well, the well construction in the geothermal horizon is an extremely important aspect (Soboń 2006). As previously, each of the above types of construction is dedicated to different geologic conditions and in some cases it can be the only solution allowing the conversion of the well for geothermal purposes (Soboń 2006):

- open-hole type is used for firm, often fractured rock, which assures stability of borehole's walls. In this case, the last casing ends above the ceiling of reservoir horizon, remaining it uncased. This solution provides appropriate hydrodynamic conditions and is characterized by low costs;

- filter construction is used when the borehole is unstable, e.g. for porous horizons, such as sandstones. Filter is applied directly in the reservoir horizon interval (Fig.2B), however, it is also possible to use casing with drilled interval;

- filter construction with borehole widening and gravel packing (Fig.2A) should be used within relevantly porous rock, characterized by an adequate stability of wellbore. The reservoir horizon is drilled through and then the diameter is enlarged optionally up to the range of 12-15", thereby increasing the well 
capability Afterwards, the filter construction is run down the borehole and gravel packing (of a proper grain size) is made (Kępińska and Bujakowski (eds.) 2011). It is probably the most sufficient solution for an injection well, providing optimal hydrodynamic conditions;

- cased-hole type might be employed to make closed reservoir horizons accessible once again. It requires making perforation holes made through the socalled blockade between the reservoir horizon and the wellbore, providing the hydrodynamic contact. This construction is said to be of low hydrodynamic efficiency, however, in some cases it might be the only solution for existing wells to be adapted for geothermal purposes.

\section{Selected Geothermal Wells in Poland}

Currently, as it was mentioned before, six geothermal district heating plants are operating in Poland, i.e. Pyrzyce, Mszczonów, Uniejów, Poddębice, Stargard and Podhale (Kępińska 2015; Kępińska 2016). These plants have exploited thermal waters from the Jurassic and Triassic sedimentary formation within the Polish Lowlands and Eocene carbonates in case of Podhale region. The types of wells and methods for accessing geothermal horizons can be seen in the Table 1. As can be noticed (Tab.1), among these boreholes, in eight cases horizon has been render accessible by a perforation of casing, in five wells the filter construction with borehole widening and gravel packing has been implemented, whereby within two wells uncased intervals occurred (Kępińska and Bujakowski (eds.) 2011).

Since, the construction of conventional geothermal well has been presented previously (section 4), it has been decided to present the construction of the borehole which was the subject of the successful reconstruction process - the Mszczonów IG-1 Well.

Tab.1. Production and injection wells in Polish DH Plants; based on (Kępińska and Bujakowski (eds.) 2011; Uliasz-Misiak and Dubiel 2015).

\begin{tabular}{ccccc}
\hline DH Plant & Well ID & Kind of Well & Well Axis & Access to Reservoir \\
\hline Pyrzyce & Pyrzyce GT-1 & production & vertical & filter with widening \\
& Pyrzyce GT-2 & injection & vertical & filter with widening \\
& Pyrzyce GT-3 & production & vertical & filter with widening \\
& Pyrzyce GT-4 & injection & vertical & filter with widening \\
\hline Mszczonów & Mszczonów IG-1 & production & vertical & casing perforation \\
\hline Uniejów & Uniejów PIG/AGH-1 & injection & vertical & casing perforation \\
& Uniejów PIG/AGH-2 & production & vertical & casing perforation \\
& Uniejów IGH-1 & injection & vertical & casing perforation \\
\hline Stargard & Stargard Sz. GT-1 & production & vertical & filter with widening \\
& Stargard Sz. GT-2 & injection & directional & widening/open-hole \\
\hline Podhale & Bańska IG-1 & production & vertical & casing perforation \\
& Bańska PGP-1 & production & vertical & casing perforation/open- \\
& Bańska PGP-3 & production & directional & filter construction \\
& Biały Dunajec PAN-1 & injection & vertical/ & casing perforation/open \\
& & & directional after & reconstruction \\
& Biały Dunajec PGP-2 & injection & vertical & casing perforation \\
\hline
\end{tabular}




\section{The Mszczonów IG-1 Well}

The geothermal water intake from the Mszczonów IG-1 well and the Geothermal Plant are located within administrative borders of Mszczonów. It is the town located in the Masovian Voivodship - central Poland (Fig.1), within geological structure of the Warsaw trough (Bujakowski et al. 2017).

The Mszczonów IG-1 well was drilled on the cusp of 1976 and 1977 to the depth of 4,119 m, leading geostructural research, and exploration for oil and gas resources (Bujakowski et al. 2017). Since the geologic goal was achieved without the presence of hydrocarbons, the borehole was completely liquidated and the drilling site was reclaimed (Bielec and Balcer 2015; Bujakowski 2015). In the period from 1996 to 1999 the first (in Poland) total reconstruction of exploratory well, aimed at the restoration of technical condition of the borehole enabling safe and stable exploitation of geothermal waters, was held (Bujakowski 2015; Bujakowski et al. 2017). In terms of reconstruction, the methodology developed at the Mineral and Energy Economy Research Institute of the Polish Academy of Sciences was implemented, comparting the process into two, substantial phases - technical works and field test (Bujakowski et al. 2017). The technical work included drilling, well protection issues, access to the reservoir zone, as well as introduction of installations and operating devices, whereas, tests concerned disparate pumping (i.e. scrubbing, metering, pre-exploitative), as well as hydrodynamic, geophysical, mineralogicalpetrographic, physico-chemical and isotopic studies (Bujakowski 2015).

The proceeded works allowed the opening of the Geothermal Plant in 2000, and use of the Mszczonów IG-1 well (Fig.3) for the exploitation of thermal waters. The Mszczonów IG-1 well works in a failure-free mode in the single well (open) geothermal system, harnessing thermal water at the depth between $1,600-1,700 \mathrm{~m}$, from Lower Cretaceous horizon (sandstones). Considering the issue of the construction (Fig.3), the Mszczonów IG-1 well is a vertical borehole, the reservoir of thermal water is accessible by the casing perforation within aforementioned depth interval. Since the formation is under the sub-artesian pressure, the pumping equipment is necessary (Bujakowski 2015). The temperature of the thermal water is measured as $42^{\circ} \mathrm{C}$ and the amount of total dissolved solids (TDS) equal to $0.5-0.6 \mathrm{~g} / \mathrm{dm}^{3}$ (Tomaszewska 2015). The main method for the utilization of geothermal medium remains space heating. Additionally, after cooling and proper treatment, it is sent to the municipal water supply and used for drinking purposes, which is rare on the European scale. Moreover, since 2008, thermal water has supplied the recreational facility Termy Mszczonowskie (Bujakowski et al. 2017).

\section{Conclusion}

Geothermal energy is considered ecological and sustainable source of renewable energy that can become the alternative for the future energy sector in Poland, especially in the context of space heating and hot water supply. Being endowed with low-temperature resources, Poland has also the high opportunity to develop the sector of recreation and balneotherapy, also the agriculture and industrial applications are feasible. Besides a few simplifications, exploitation of geothermal energy resources is connected with an obligatory accomplishment of formalities resultant from binding law and formal requirements, such as The Geologic and Mining Law, The Water Law, The Environmental Protection Law and numerous regulations. Fulfilling all the formalities, there is still an extremely important, and complex issue of a geothermal well construction and selection of exploitation system. 


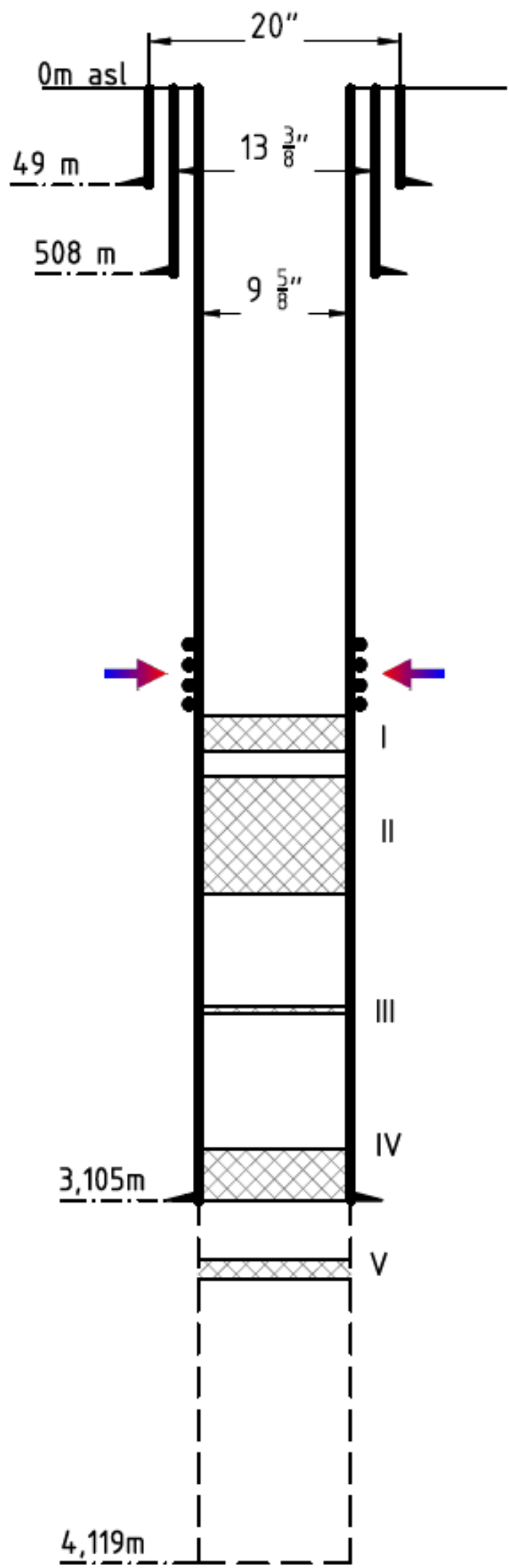

Geographical coordinates:

longitude: $20^{\circ} 32^{\prime} 48^{\prime \prime}$

latitude: $51^{\circ} 58^{\prime} 30^{\prime \prime}$

height ast: $171.33 \mathrm{~m}$

Stratigraphic profile [m bgl]:

0.0-123.0 Quaternary

123.0-233.5 Neogene

233.5-311.0 Paleogene

311.0-1,568.5 Upper Cretaceous

1,568.5-1,735.0 Lower Cretaceous

1,735.0-2,308.5 Upрeг Jurassic

2,308.5-2,443.0 Middle Jurassic

2,443.0-2,782.0 Lower Jurassic

2,782.0-3,205.0 Upper Triassic

3,205.0-3,307.5 Middle Triassic

3,307.5-3,656.0 Lower Triassic

3,656.0-4,061.0 Permian - Zechstein

4,061.0-4,061.5 Permian - Rotliegend

4,061.5-4,119.0 Carboniferous (Silesian)

- Casing perforation [m bgl]:

$1,602.5-1,645.5$

$1,663.5-1,714.0$

ए Cement plugs [m bgl]:

I - 1,750.0-1,850.0

II $-1,920.0-2,247.0$

III - 2,561.0-2,580.0

IV - 2,960.0-3,130.0

$V-3,270.0-3,324.0$

Fig.3. The schematic design of Mszczonów IG-1 well after the reconstruction process; based on (Bujakowski 2015; Bujakowski et al. 2017, CBDG PIG-PIB 2018). 
This phase is an inherently connected with geology (tectonic lithology, etc.), which determines vast majority of operational parameters of a potential installation. The formation pressureremains the particularly important issue that influences the construction of a well and required devices. The designing phase has to take cognizance of aforementioned aspects, not omitting the issue of possible re-adaptation of old exploratory (or petroleum) wells. Considering the Mszczonów IG-1 well, it was proved that it is possible to create successful geothermal system working on the basis of an old, reconstructed well.

\section{Acknowledgement}

The paper has been prepared under the AGHUST statutory research grant No. 11.11.140.031 and grant No. 15.11.140.189.

\section{References}

Bielec B., Balcer M. (2015) Wieloletni monitoring eksploatacji złoża wód termalnych, stanu technicznego odwiertu Mszczonów IG-1 i strefy złożowej. Technika Poszukiwań Geologicznych 1: 37-57 (in Polish).

Biernat H., Noga B., Kosma Z. (2012): Przegląd konstrukcji archiwalnych i nowych otworów wiertnicznych wykonanych na Niżu Polskim w celu pozyskiwania energii geotermalnej. Modelowanie Inżynierskie 44: 21-28 (in Polish).

Brown D.W., Duchane D.V., Heineken G., Hriscu V.T. (2012) The Enormous Potential of Hot Dry Rock Geothermal Energy. [In:] Mining the Earth's Heat: Hot Dry Rock Geothermal Energy, Springer Science \& Business Media, 17-44.

Bu X., Ma W., Li H., (2012) Geothermal energy production utilizing abandoned oil and gas wells. Renewable Energy 41: 8085.

Bujakowski W., Barbacki A., Skrzypczak R. (2013) New directions of research in the Polish part of the Sudetic area in the aspect of HDR and EGS technologies. Przegląd Geologiczny 61, 11: 706-711 (in Polish, abstract in English).

Bujakowski W., Tomaszewska B. (eds.) (2014) Atlas of the possible use of geothermal waters for combined production of electricity and heat using binary system in Poland. MEERI PAN Publ., Kraków.

Bujakowski W. (2015) Rekonstrukcja odwiertu Mszczonów IG-1 na tle innych, wybranych rekonstrukcji otworów geotermalnych. Technika Poszukiwań Geologicznych 1: 17-34 (in Polish).

Bujakowski W., Tomaszewska B., Miecznik M. (2016) The Podhale geothermal reservoir simulation for long-term sustainable production. Renewable Energy 99: 420-430.

Central Geological Database of the Polish Geological Institute - National Research Institute, abbr CBDG PIG-PIB; Otwory wiertnicze.(Website: last accessed $26^{\text {th }}$ June, 2018 http://otworywiertnicze.pgi.gov.pl/; Entries: Mszczonów).

Gonet A., Capik M., Śliwa T. (2006) Technique of drilling wells. [In:] Górecki W. (eds.) (2006) Atlas of Geothermal Resources of Mesozoic Formations in the Polish Lowlands. AGH Publ., Kraków.

Górecki W. (eds.) (2006) Atlas of Geothermal Resources of Mesozoic Formations in the Polish Lowlands. AGH Publ., Kraków, p. 54-59.

Górecki W., Sowiżdżał A., Hajto M., Wachowicz-Pyzik A. (2015) Atlases of geothermal waters and energy resources in Poland. Environmental Earth Sciences 74: 7487-7495. 
Kępińska B. (2016) Geothermal Energy Use Country Update for Poland, 2013-2015, EGC Proceedings, Strasbourg, France.

Kępińska B. (2015) Geothermal Energy Country Update Report from Poland, 20102014, WGC Proceedings, Melbourne, Australia.

Kępińska B., Bujakowski W. (eds.) (2011) Wytyczne projektowe poprawy chłonności skał zbiornikowych $\mathrm{w}$ związku $\mathrm{z}$ zatłaczaniem wód termalnych $\mathrm{w}$ polskich zakładach geotermalnych. EJB Publ., Kraków.

Kristmannsdóttir H., Ármannsson H., (2003) Environemntal acpects of geothermal energy utilization. Geothermics 32, 4-6: 451-461.

Lacirignola M., Blanc I. (2013) Environmental analysis of practical design options for enhanced geothermal systems (EGS) through life-cycle assessment. Renewable Energy, 50: 901-914.

Miecznik M., Sowiżdżał A., Tomaszewska B., Pająk L. (2015) Modelling geothermal conditions in part of the Szczecin Trough the Chociwel area. Geologos 21, 3: 187196.

Olasolo P., Juárez M.C., Morales M.P., D'Amico S., Liarte I.A. (2016) Enhanced Geothermal Systems (EGS): A Review. Renewable and Sustainable Energy Reviews, 56: 133-144.

Røksland M., Basmoen T.A., Sui D., (2017) Geothermal Energy Extraction from Abandoned Wells. Energy Procedia 105: 244-249.

Soboń J. (2006) Design of production and injection wells completed in the zone of geothermal reservoir horizons. [In:] Górecki W. (eds.) (2006) Atlas of Geothermal Resources of Mesozoic Formations in the Polish Lowlands. AGH Publ., Kraków.

Sowiżdżał A., Tomaszewska B., Drabik A. (2017) Environmental aspects of the geothermal Energy utilisation in Poland. E3S Web of Conferences 22.

Sowiżdżał A. (2018) Geothermal energy resources in Poland - overview of the current state of knowledge. Renewable and Sustainable Energy Reviews 82: 40204027.

Sowiżdżał A., Kaczmarczyk M. (2016) Analysis of thermal parameters of Triassic, Permian and Carboniferous sedimentary rocks in central Poland. Geological Journal 51: 65-76.

Tomaszewska B., Hołojuch G., (2012) Geothermal Energy production on the background of the new legal regulations. Biuletyn Państwowego Instytutu Geologicznego 448, 2: 281-284 (in Polish, abstract in English).

Tomaszewska B., Pająk L. (2012) Dynamics of clogging processes in injection wells used to pump highly mineralized thermal waters into the sandstone structures lying under the Polish Lowlands. Archives of Environmental Protection 38, 3: 105-117.

Tomaszewska B. (2015) Warunki hydrogeotermalne w regionie Mszczonowa. Technika Poszukiwań Geologicznych, Geotermia, Zrównoważony Rozwój 54, 1: 81-94 (in Polish).

Uliasz-Misiak B., Dubiel S. (2015) Problems of geothermal wells workover operations. Przegląd Górniczy 7: 55-61 (in Polish; abstract in English).

\section{Legal Regulations:}

The Geologic and Mining Law - Ustawa Prawo Geologiczne i Górnicze (Journal of Laws of 2016 item 1131) (in Polish).

The Water Law - Ustawa Prawo Wodne (Journal of Laws of 2017 poz. 1566) (in Polish).

The Environmental Protection Law - Ustawa Prawo Ochrony Środowiska (Journal of Laws of 2017 item 519) (in Polish). 
The Regulation of the Minister of Environment - Rozporządzenie Ministra Środowiska w sprawie szczegółowych wymagań dotyczących projektów robót geologicznych, w tym robót, których wykonywanie wymaga pozyskania koncesji (Journal of Laws of 2015 item 964) (in Polish).

The Regulation of the Council of Ministers Rozporządzenie Rady Ministrów w sprawie przedsięwzięć mogących znacząco oddziaływać na środowisko (Journal of Laws of 2016 item 71) (in Polish).

The Regulation of the Minister of Environment - Rozporządzenie Ministra Środowiska w sprawie dokumentacji hydrogeologicznej i dokumentacji geologiczno-inżynierskiej
(Journal of Laws of 2016 item 2033) (in Polish).

The Regulation of the Minister of Environment

- Rozporządzeniem Ministra Gospodarki w sprawie szczegółowych wymagań dotyczących prowadzenia ruchu zakładów górniczych wydobywających kopaliny otworami wiertniczymi, zatłaczanie wody do górotworu (Journal of Laws of 2014 item 812) (in Polish).

The Act on Access to Information about Environment - Ustawa o udostępnianiu informacji o środowisku i jego ochronie, udziale społeczeństwa w ochronie środowiska oraz o ocenach oddziaływania na środowisko (Journal of Laws of 2017 item 1405) (in Polish). 